УДК 342.7

DOI https://doi.org/10.51989/NUL.2021.5.6

\title{
АДВОКАТ ЯК НОСІЙ ПРОФЕСІЙНОЇ ПРАВОВОЇ КУЛЬТУРИ СУСПІЛЬСТВА
}

\author{
Ємельяненко Карім Олегович, \\ кандидат юридичних наук, адвокат, \\ старший викладач кафедри теорії та історії держави і права \\ Національного університету біоресурсів і природокористування України
}

У статті проаналізовано загальнотеоретичні основи професійної правової культури інституту адвокатури та розглянуто адвоката як носія професійної правової культури суспільства. Автором здійснена спроба дослідити професійні норми діяльності адвокатури як професійної спільноти в суспільстві - від практичної діяльності адвоката, через володіння та вміння користуватись правовими знаннями, до особистих моральних якостей, якими має володіти сучасний адвокат або правник, а також дослідити усвідомлення професійної і суспільної значущості адвокатом своєї ролі в суспільстві, відповідності їі інтересам правової держави і громадянського суспільства загалом. Автором статті звертається увага на внутрішню сутність професійної правової культури адвоката, як окремого професіонала-правника, так і інституту адвокатури в суспільстві. Автором досліджуються визначення та правова природа таких понять, як «правова культура», «правова свідомість» у декількох філософсько-правових та загальнотеоретичних підходах, тотожність сприйняття цих понять серед зарубіжних фахівців і адвокатських спільнот; наводиться характеристика етичних норм, закріплених внутрішніми актами адвокатської інституції, дотримуватись яких має кожен адвокат; наголошується на окремих якостях адвоката як зобов'язувальної складової частини в підтриманні авторитету адвокатури в суспільстві порівняно з державними органами влади; підтримується думка щодо визначення правової культури як способу організації правової життедіяльності учасників суспільного життя через правові цінності та правові орієнтації в суспільстві. У межах статті автором відзначаються декілька особливих бачень учених-теоретиків та практиків про служіння адвоката суспільству. Однак автором підтримується і власне переконання щодо призначення та поклику у професії адвоката, яка нині вимагає посилення та розширення деонтологічних засад професіоналізму - підвищення рівня професійної правової культури, політичної, суспільної складових частин, моральних якостей щодо справи.

Ключові слова: правова культура, правосвідомість, адвокат, адвокатура, суспільство, правові цінності, етика.

\section{Yemelianenko Karim. Advocate as a carrier of high legal culture of society}

The article analyzes the general theoretical basis of professional legal culture at the Institute of the Bar, considers the lawyer as the bearer of the high legal culture of society. The author made an attempt to research the professional norms of the legal profession as a professional community in society - from the practice of a lawyer through possession and ability to use legal knowledge to personal moral qualities that a modern lawyer or jurist should have, and also the author made an attempt to study the awareness of the professional and social significance of a lawyer of his role in society, its compliance with the interests of the rule of law and civil society as a whole. The author of the article draws attention to the inner essence of the professional legal culture of a lawyer as an individual professional lawyer and the institution of the legal profession in society. The author investigates the definitions and legal nature of such concepts as legal culture, legal consciousness in many philosophical, legal and general theoretical approaches; identity of perception of these concepts among foreign experts and their legal communities; identity of perception of these concepts among foreign experts and their legal communities; the author provides a description of the ethical standards adopted by the internal acts of the legal institution and which each lawyer must follow; the author focuses on the individual qualities of a lawyer as an obligatory component in maintaining the authority of the legal profession in society in comparison with state authorities; the author supports the thesis regarding the definition of legal culture as a way of organizing the legal activity of participants in the life of society through legal values and legal orientations in society. Within the framework of the article, the author notes several special views of scientists-theorists and practitioners about the service of a lawyer to 
society. However, the author also insists on his own conviction regarding the purpose and vocation in the profession of a lawyer, which today requires strengthening and expanding the deontological foundations of professionalism - raising the level of professional culture, political and social components, moral qualities in relation to the case.

Key words: legal culture, legal consciousness, advocate, advocacy, society, legal values, ethics.

Дослідження проблематики правової культури суспільства залишається актуальним у професійному середовищі правників України. Зокрема, особливу увагу професійній правовій культурі приділяє український інститут адвокатури, про що свідчать внутрішні норми та правила адвокатського самоврядування і що слушно зазначають дотичні до професії фахівці та профільні представники наукового середовища. у структурі правової культури в межах загальної культури в повсякденному житті суспільства існують та використовуються сталі правила поведінки і взаємин людей один з одним на підставі загальновизнаних соціальних та інших цінностей. Тому в тісному спілкуванні та взаємодії групи осіб, що об'єднані за професійною належністю, виробляються правила поведінки з установленням відповідних норм саме для професійної спільноти, зокрема адвокатури. У сучасному житті суспільства саме адвокатура відіграє роль реального захисника тих цінностей, принципів, поглядів та інтересів суспільства, що становлять основу професійної культури сучасного юриста й адвоката, спрямовують тим самим суперечливі явища невизначеної об'єктивної дійсності в русло законності та потреб нормотворчого вдосконалення правової культури. I кожен член адвокатської спільноти, здійснюючи свою професійну діяльність, несе в собі взаємозв'язок особистих та професійних якостей, таким чином, істотно впливає на правопорядок в суспільстві та професійну правову культуру загалом. Варто зазначити, що розгляд адвоката як носія професійної правової культури суспільства здебільшого досліджувався в аспекті етичної культури. Однак генеза розвитку наукової думки в цьому напрямі й одержані результати потребують розширення меж наукового пізнання адвокатської інституції, зокрема в аспекті професійної правової культури суспільства.

Питаннями досліджуваної нами проблематики активно переймалися як вітчизняні вчені, так і знані фахівці правової культури зарубіжжя, зокрема: В.Б. Авер'янов, П.М. Рабінович, А.Б. Венгеров, В.В. АлексєєВ, В.В. Ладиченко, Л.О. Макаренко, В.О. Качур, С.Р. Станік, Ю.С. Шемшученко, Ю.М. Оборотов, Є.І. Федик, М.Ф. Целуйко, О.М. Дроздов, Б.О. Чупринський, В.М. Сущенко, М.Р. Аракелян, В.С. Нерсесянц, Е.С. Насурдінов та інші.

Метою цього дослідження $\epsilon$ визначення загальнотеоретичних основ професійноправової культури інституту адвокатури та розгляд адвоката як носія професійної правової культури суспільства.

Культура в сучасному розумінні $\epsilon$ поняттям багатогранним та багатоаспектним. I право $€$ одним з інститутів сучасної культури незалежно від нормативного закріплення чи юридичної реґламентації тих чи інших норм культури, зокрема правової. Варто звернутися до наукового визначення поняття правової культури. За визначенням знаного вітчизняного науковця Ю.С. Шемшученка, правова культура - це система духовних і матеріальних цінностей у сфері функціонування права, складова частина загальної культури, що охоплює всю сукупність найважливіших ціннісних компонентів правової реальності в її розвитку (тобто право, правосвідомість, правовідносини, правопорядок, нормотворча, правозастосовна й інша правова діяльність) і $€$ однією з категорій загальнолюдських цінностей, невід'ємним компонентом правової держави [1, с. 37]. Як зазначає сучасна дослідниця В.О. Качур [2], у науковій літературі констатується факт відсутності однозначного підходу до розуміння правової культури. На її переконання, правова культура $\epsilon$ одним із різновидів загальної культури, що становить її самостійний розділ, $\epsilon$ синтезом права та культури, характеризується автономністю щодо інших різновидів культури (матеріальна, економічна, політична тощо). Тоді як за визначенням вітчизняного вченого П.М. Рабіновича правова 
культура - це загальний стан «юридичних справ» у суспільстві, тобто стан законодавства і роботи суду, усіх правоохоронних органів, правосвідомості всього населення країни, що виражає рівень розвитку права і правосвідомості, їхнє місце в житті суспільства, засвоєння правових цінностей, їх реалізацію на практиці, здійснення вимог верховенства права [3, с. 5].

Сучасним вітчизняним ученим-філософом А.Є. Конверським поняття та вимір правової культури пропонується розглядати у трьох аспектах - філософському, теоретико-правовому, соціологічному. Як зауважується вченим, прищеплення правової культури повинне розпочинатись якнайраніше i продовжуватись протягом усього життя особистості, наголошується на обов'язковості правової освіти, а також на потребі формування професійного корпусу правознавців, які повинні займатися не лише практичними проблемами правотворчості і правозастосування, але насамперед ревним служінням ідеї права, іï втіленням у нормах і принципах законодавства [4, с. 7]. Іншим вітчизняним дослідником О.А. Ануфрієнком [5, с. 12] у філософсько-правовому аналізі професійної правової культури було впроваджено поняття «професійно-політична культура юриста» як службово-функціональний складник його політичної культури, що характеризує його рівень професійної підготовленості та службової діяльності, пов'язаної з участю у правовому регулюванні політичної системи. Дослідником також наголошувалось на таких компонентах моделі професійно-політичної культури сучасного українського юриста, як природно-правова політична значущість, професійне державотворче політичне самовизначення та професійна політико-правова відповідальність юриста. Тобто сучасний юрист-професіонал деякими вченими розглядається і як суспільний, державний, політичний діяч, який так чи інакше бере участь у суспільних та політичних процесах та впливає на професійну правову культуру суспільства.

У загальній теорії права під правовою культурою розуміють якісний стан правового життя суспільства, який характеризується досягнутим рівнем розвитку правової системи - станом та рівнем пра- вової свідомості, юридичної науки, системи законодавства, правозастосовної практики, законності і правопорядку, правової освіти, а також ступенем гарантованості основних прав і свобод людини.

Доречно було би звернути увагу і на правосвідомість як на особливий вид суспільної свідомості, зокрема на професійну правосвідомість адвоката, який $€$ безумовним носієм професійно-юридичної свідомості. Багато філософських підходів [6, с. 44] несуть у собі переконання, що правова свідомість $€$ вираженням смислового аспекту правової реальності. Так, на переконання вченого О.Г. Спіркіна, правосвідомість визначається як уявлення і поняття, що виражають ставлення людей до чинного права, знання міри в поведінці людей із погляду права й обов'язків; це правові теорії, правова ідеологія тощо [7, с. 722]. У юридичній і філософській літературі також існує досить значна кількість визначень поняття «правосвідомість», основним елементом яких зазначаються правова ідеологія і правова психологія, однак не завжди. Так, ученим Н.I. Бровко поняття «правосвідомість» досліджується як процес, що складається 3 декількох стадій, за допомогою якого люди сприймають свій досвід, спираючись на правові категорії і поняття. Досить критично ним сприймається визначення правосвідомості зарубіжними професійними правовими спільнотами, зокрема ним наголошується на неприпустимості ототожнення понять «правосвідомість» та «правова грамотність» представниками Канадської асоціації адвокатів. Отже, ученим наголошується на відмінності сприйняття та бачення вітчизняних та зарубіжних фахівців щодо означених понять, де під «правовою грамотністю» мається на увазі здатність розуміти слова, що використовуються в юридичному контексті, робити висновки з них, потім використовувати ці висновки для вжиття відповідних заходів [8, с. 195].

Загалом в юридичній літературі правова свідомість розглядається на трьох рівнях повсякденному, спеціалізованому (професійному), науковому. На наш погляд, саме адвокатська діяльність $\epsilon$ одним із професійних напрямів в юридичній професії, що здатна виходити за межі професійної правової культури та правосвідомості. 
Як зазначає дослідник Б.О. Чупринський $[6$, с. 51, 57], предметна діяльність суб'єктів у певній галузі правового регулювання під час розгляду юридичних справ, підготовки індивідуально-владних приписів потребує спеціалізованого (професійного) рівня правосвідомості, за допомогою якого пізнаються й оцінюються правові явища з метою їх практичного використання у процесі правозастосовної діяльності. За логікою вченого, саме система спеціалізованих умінь, знань і навичок формує професійну правосвідомість сучасного юриста, що $\epsilon$ більш глибокого порядку, ніж повсякденні уявлення про правові норми і розуміння їх членами суспільства. Погоджуємося з таким баченням загалом, проте, на наш погляд, варто враховувати і сучасні обов'язкові особистісні надпрофесійні навички (soft-skills), що вже сформувались в оновленій сучасній адвокатській спільноті, в інших юридичних спеціальностях.

Загалом, як відзначив один із ключових вітчизняних теоретиків С.С. Алексєєв, юрист - це особа, обізнана в юриспруденції, наділена професійними правовими знаннями, яка вміє застосовувати їх у практичній діяльності [9, с. 73-74].

На наше переконання, правова культура має досить суб'єктивне визначення в науковому середовищі, оскільки поєднана із правовими цінностями та ціннісними настановами щодо правових явищ та процесів щодо розвитку права, держави і суспільства загалом. Тому професійна діяльність фахової людини, що пов'язана передусім із реалізацією правових цінностей, відображається і в культурних процесах правового життя суспільства. А отже, і правова, і професійна культура суспільства загалом може містити елементи правової культури окремих соціальних груп, професій, фахівців чи юридичних спільнот із відповідними цінностями та сформованими локальними нормами. Носіями правової культури можуть бути суспільство загалом, особистість або професійна спільнота. Саме тому нами наголошується, що адвокатура як інституція та члени адвокатської спільноти, усвідомлюючи рівень моральної відповідальності у своїй професійній діяльності, так чи інакше впливають на рівень правової культури суспільства загалом.
Як і в багатьох країнах, в Україні адвокат має як соціально-правовий, так і професійно-правовий статус, що визначено Конституцією України та Законом України «Про адвокатуру та адвокатську діяльність» [10].

Адвокат у своїй професійній діяльності, окрім реалізації на практиці своїх професійних знань, інтелекту й ерудованості в законодавстві, має усвідомлювати у своїх діях соціальний, культурний, моральний аспекти та відповідально ставитись до результатів своєї діяльності, зважаючи на суспільний ефект. Науковцями досить неоднозначно сприймається суспільне призначення адвокатури за наявності відповідного процесуального та суспільного статусу у професійній правовій культурі загалом. Як зазначив один із сучасних дослідників інтелектуальної культури юриста Ю.М. Занік [11, с. 12], зміст інтелектуальної культури зумовлюється сутністю кожного окремого носія, тобто характерними рисами, властивостями, інтелектуальним потенціалом конкретного правника. На його переконання, інтелектуальна культура юриста повинна бути невіддільною від моральної культури особистості; бути не тільки свідченням цивілізованості особи (рівень освіченості), але і ознакою культурності (духовності); за своїм соціальним призначенням сприяти створенню в суспільстві умов упорядкованості, які 6 були юридично забезпеченими, дозволили 6 людині здійснювати та захищати свої природні права.

Безумовно, у суспільстві адвокат сприймається як моральний авторитет, незважаючи на дії окремих представників професії, що дозволяють собі не дорожити професійним статусом у суспільстві. у сучасних професійних колах українських правників [12] особливу увагу завжди привертала проблема співвідношення мети та засобів у діяльності адвоката. Для адвокатури моральна оцінка важливіша, ніж для багатьох державних органів. I $\epsilon$ неприйнятним досягнення мети будь-якими засобами - допустимо діяти лише у правових межах. Так, якщо авторитет державних органів спирається на владні повноваження і підтримку всього державного апарату, то авторитет адвокатури має одну опору - суспільну 
довіру, яку досить важко набути і легко втратити, особливо в такій конфліктній сфері, як робота адвоката в суді. В адвокатській спільноті часто-густо наводиться вислів видатного адвоката Ф.Н. Плевако: «За прокурором стоїть закон, а за адвокатом - людина зі своєю долею, зі своїми сподіваннями, і ця людина піднімається на адвоката, шукає в нього захисту, і дуже страшно посковзнутися з такою ношею». Тому, як зауважують практики з адвокатської спільноти, участь у вирішенні правових конфліктів вимагає від адвоката дотримання певних морально-етичних вимог. У цьому аспекті сучасними зарубіжними вченими теорії та філософії права [13, с. 23, 25] юридична етика сприймається як професійна етика, що є практичним вираженням та втіленням етики права у фахівця-професіонала. Однак водночас наголошують на гострій складовій частині суто юридичної етики, коли у фахового юриста, зокрема члена адвокатської спільноти, знання можуть суперечити внутрішній моральній та суспільній складовим частинам, нормі закону. І оскільки сфера професійної діяльності юриста $\epsilon$ досить широкою, то морально-правова та професійна юридична позиція юриста впливають одна на одну, зобов'язують постійно здійснювати важкий моральний вибір. В адвокатурі України такою місією перейнялись ії самоврядні органи разом з ухваленням Правил адвокатської етики, де адвокатурі відведено роль єдиного незалежного недержавного самоврядного інституту, що забезпечує здійснення захисту, представництва та надання інших видів правової допомоги на професійній основі на закріплених Законом України «Про адвокатуру та адвокатську діяльність» [10] принципах верховенства права, законності, незалежності, конфіденційності й уникнення конфлікту інтересів, реалізується адвокатурою у складній системі правовідносин [14]. Зокрема, у преамбулі Правил адвокатської етики наголошується на надзвичайній важливості функціонального навантаження адвокатури, що вимагає від адвокатів дотримання високих етичних стандартів поведінки. Специфіка, комплексний характер обов'язків, що покладені на адвокатуру, зумовлюють необхідність збалансування засад служіння адвоката інтересам окремого клієнта й інтересам суспільства загалом, дотримання принципів законності і верховенства права. Дотримання адвокатами особливих деонтологічних вимог і правил розглядається світовою адвокатською спільнотою як необхідна передумова повноцінного функціонування адвокатури, виконання нею ії важливої соціальної ролі в демократичному суспільстві [14].

3 погляду дієвості правозахисна діяльність ефективніше реалізується і функціонує через механізми системи інститутів для реалізації конституційних прав і свобод людини і громадянина, захисту законних інтересів фізичних і юридичних осіб. Адвокатура, як недержавна правозахисна інституція, $\epsilon$ ефективнішою за державу й органи державної влади в наданні професійної юридичної / правничої допомоги в сучасному громадянському суспільстві. Як зазначає сучасний вітчизняний ученийправник М.Р. Аракелян [15, с. 61], реалізація прав і свобод людини $\epsilon$ неможливою без формування цілісної правозахисної системи, її теоретичних основ, насамперед створення відповідної законодавчої бази, удосконалення правотворчої і правозастосовної діяльності, подолання правового нігілізму та формування високої правової культури. У даному аспекті варто зважити на наукові пошуки сучасного вітчизняного правника Ж.М. Алексєєвої [16, с. 7], яка розглядає образ юриста в сучасній європейській культурі як нероздільну тріаду: юрист - суспільство - культура. Зокрема, на ії переконання, сучасний юрист як представник професійно-стратифікаційного начала не може існувати без культури і суспільства, які взаємодіють одне з одним, тобто «кожен юрист $\epsilon$ «людиною культури» - своєї специфічної культури»; відповідно особливості образу юриста залежать від типу суспільства, оскільки кожне суспільство формує на кожному етапі свого розвитку власну ідеологію - систему панівних цінностей та ідеалів. Варто зазначити, що саме через правову культуру як специфічний спосіб організації правової життєдіяльності учасників суспільного життя визначаються і проявляються правові цінності та правові орієнтації в суспільстві [17]. 
На наш погляд, також доречно звернути увагу і на практичну площину професійної правничої діяльності інституту адвокатури, адже адвокат - це професіонал, фахівець юридичної справи, що не лише володіє і використовує у своїй професійній діяльності юридичні знання, але і за своїм особистим покликом $€$ носієм та безпосереднім учасником у розбудові професійної правової культури суспільства. Як зазначив сучасний український учений В.М. Сущенко [18], ціннісна орієнтація і професійна майстерність адвоката залежать від усвідомлення ним системи правових цінностей та етичних норм у суспільстві, високого рівня культури його поведінки, людської та професійної гідності, стриманої тактовності, самоконтролю в повсякденній поведінці. Діяльність сучасного українського адвоката зумовлена престижністю юридичної професії та повагою до її представників із боку суспільства. Вона ґрунтується на таких принципах: безумовного дотримання у своїй діяльності доктрини «верховенства права» та її складових частин; неупередженості й об'єктивності; чесності та сумлінності; компетентності; відповідальності перед собою, адвокатською спільнотою, суспільством за якість та своєчасність надання юридичних послуг. Зазначені принципи визначають рівень професійної культури адвоката, зміст якої полягає в опануванні кожним правником системи загальнокультурних і професійних цінностей, створених та сформованих різними поколіннями етнічних, національних і регіональних людських спільнот, а також носіями цієї професії [18].

У зв'язку з динамічним розвитком та впровадженням цифрової складової частини в усіх сферах життєдіяльності можна відзначити підвищену затребуваність про- фесійної правової культури в сучасному суспільстві. Адже вміння використовувати правові знання, реалізовувати і захищати свої суб'єктивні права і законні інтереси нині потребує і трендових технічних навичок, якими володіє сучасний правник у професії адвоката, і фундаментальних навичок - складових частин правової культури: етики, естетики, філософії права, історичного та практичного досвіду, об'єктивної оцінки й особистого відчуття правової дійсності. Саме адвокат як носій професійної правової культури суспільства, усвідомлюючи соціальну доцільність своїх професійних знань, $є$ як морально, так і професійно відповідальним за результати своєї діяльності. Як нами вже зазначалось, академічні погляди вчених щодо суспільного призначення адвокатури як професійної юридичної спільноти різняться. Служіння адвоката суспільству одними вченими досить переконливо відзначається у філософсько-правових і аналітичних підходах, однак інші вчені вважають, що адвокат захищає інтереси клієнта, навіть за відсутності мотивації щодо отримання винагороди чи суспільних благ. Професія адвоката натепер вимагає посилення та розширення деонтологічних засад професіоналізму - підвищення рівня професійної правової культури, політичної, суспільної складової частини, моральних якостей у ставленні до справи. Невід'ємною частиною правової культури адвоката $\epsilon$ його правова свідомість, яку формують і на яку впливають як особистісні чинники, так і зовнішні суб'єкти впливу щодо сприйняття й оцінки адвокатом правової дійсності й ухвалення рішень. Тому в сучасному суспільстві саме адвокат $\epsilon$ носієм правової культури, за яким стоїть фахова місія обстоювання справедливості через високий рівень знань, досвіду та виняткових особистих якостей.

\section{ЛITEPATУРA:}

1. Юридична енциклопедія : у 6-и т. / відп. ред. Ю.С. Шемшученко. Київ : Укр. енцикл., 1998-2004. Т. 5 : П-С. 736 с.

2. Качур В.О. До визначення поняття «правова культура» у правознавстві. Право. Людина. Довкілля : науково-практичний журнал. 2019. Vol. 10 (1). URL: http://journals.nubip.edu.ua/ index.php/Pravo/article/view/law2019.01.002/11035.

3. Рабинович П.М. Основы общей теории права и государства : учебное пособие. ХарьКов : Консум, 2005. 320 с.

4. Конверський А.Є. Філософія права як чинник формування правової культури. Правова культура - основа державотворення в Україні : збірник наукових праць. Ірпінь, 2005. Вип. 1. С. 7-11. 
5. Ануфрієнко О.А. Професійно-політична культура юриста (філософсько-правовий аналіз) : автореф. дис. ... канд. юрид. наук: 12.00.12. Київ, 2007. 18 с.

6. Чупринський Б.О. Філософсько-правові аспекти формування професійної культури майбутніх юристів : монографія. Луцьк : ФОП Захарчук В.В. 2012. 144 с.

7. Спиркин А.Г. Философия : учебник. Москва : Гардарика. 1998. С. 722-723.

8. Бровко Н.І. Філософсько-правовий аналіз категорії «правосвідомість». Юридичний електронний журнал. 2017. № 1. URL: http://lsej.org.ua/1_2017/51.pdf.

9. Алексеев С.С. Введение в юридическую специальность : учебное пособие. Москва : Юрид. лит., 1976. 256 с.

10. Про адвокатуру та адвокатську діяльність : Закон України від 5 липня 2012 р. № 5076VI. URL: https://zakon.rada.gov.ua/laws/show/5076-17\#Text (дата звернення: 09.09.2021).

11. Занік Ю.М. Інтелектуальна культура юриста : філософсько-правовий аспект : автореф. дис. ... канд. юрид. наук: 12.00.12. Київ, 2006. 16 с.

12. Пономаренко Д.В. Коротко про сутність адвокатської діяльності. 29.08.2018. URL: https://barristers.org.ua/news/korotko-pro-sutnist-advokatskoyi-diyalnosti/ (дата звернення: 09.09.2021).

13. Букреев В.И., Римская И.Н. Этика права: От истоков этики и права к мировоззрению : учебное пособие. Москва : Юрайт, 1998. 336 с.

14. Правила адвокатської етики : Установчий з'їзд адвокатів України від 17 листопада 2012 p. URL: https://zakon.rada.gov.ua/rada/show/n0003418-12\#Text (дата звернення: 09.09.2021).

15. Аракелян М.Р. Институт адвокатуры в правозащитной системе Украины : теоретикоправовой аспект : монография. Одесса, 2014. 282 с.

16. Алексєєва Ж.М. Образ юриста в сучасній європейській культурі : автореф. дис. ... канд. юрид. наук: 12.00.12. Київ, 2008. 22 с.

17. Качур В.О., Протосавіцька Л.С. Місце категорії «цінність» у теорії правової культури. Publishing House "Baltija Publishing", 2020. URL: http://www.baltijapublishing.lv/omp/index. php/bp/catalog/download/58/1049/2308-1?inline=1 (дата звернення: 09.09.2021).

18. Сущенко В.М. Модель професійної культури адвоката : критерії та підходи. Юридична газета on-line : всеукраїнське професійне юридичне видання. URL: https://yur-gazeta.com/ publications/practice/inshe/model-profesiynoyi-kulturi-advokata-kriteriyi-ta-pidhodi.html (дата звернення: 09.09.2021). 